Article

\title{
Briarenolides F and G, New Briarane Diterpenoids from a Briareum sp. Octocoral
}

Pei-Han Hong ${ }^{1,2}$, Yin-Di Su ${ }^{2,3}$, Jui-Hsin Su ${ }^{1,2,3}$, Yung-Husan Chen ${ }^{2}$, Tsong-Long Hwang ${ }^{4}$, Ching-Feng Weng ${ }^{1,5}$, Chia-Hung Lee ${ }^{1,5}$, Zhi-Hong Wen ${ }^{3}$, Jyh-Horng Sheu ${ }^{3}$, Nai-Cheng Lin ${ }^{2}$, Yueh-Hsiung Kuo ${ }^{6, *}$ and Ping-Jyun Sung ${ }^{1,2,3,5, *}$

1 Graduate Institute of Marine Biotechnology, National Dong Hwa University, Pingtung 944, Taiwan; E-Mails: peihan520@yahoo.com.tw (P.-H.H.); x2219@nmmba.gov.tw (J.-H.S.); cfweng@mail.ndhu.edu.tw (C.-F.W.); chlee016@mail.ndhu.edu.tw (C.-H.L.)

2 National Museum of Marine Biology and Aquarium, Pingtung 944, Taiwan; E-Mails: gobetter04@yahoo.com.tw (Y.-D.S.); tony_chen72001@yahoo.com.tw (Y.-H.C.); 1nc7222@hotmail.com (N.-C.L.)

3 Department of Marine Biotechnology and Resources and Division of Marine Biotechnology, Asia-Pacific Ocean Research Center, National Sun Yat-sen University, Kaohsiung 804, Taiwan; E-Mails:wzh@mail.nsysu.edu.tw (Z.-H.W.); sheu@mail.nsysu.edu.tw (J.-H.S.)

4 Graduate Institute of Natural Products, Chang Gung University, Taoyuan 333, Taiwan; E-Mail: ht1@mail.cgu.edu.tw

5 Department of Life Science and Institute of Biotechnology, National Dong Hwa University, Hualien 974, Taiwan

6 Tsuzuki Institute for Traditional Medicine, China Medical University, Taichung 404, Taiwan

* Authors to whom correspondence should be addressed; E-Mails: kuoyh@mail.cmu.edu.tw (Y.-H.K.); pjsung@nmmba.gov.tw (P.-J.S.); Tel.: +886-4-2207-1693 (Y.-H.K.); +886-8-882-5037 (P.-J.S.); Fax: +886-4-2207-1693 (Y.-H.K.); +886-8-882-5087 (P.-J.S.).

Received: 19 April 2012; in revised form: 15 May 2012 / Accepted: 22 May 2012 /

Published: 23 May 2012

\begin{abstract}
Two new briarane diterpenoids, briarenolides, F (1) and G (2), were isolated from an octocoral identified as Briareum sp. The structures of briaranes $\mathbf{1}$ and $\mathbf{2}$ were established by spectroscopic methods and by comparison of the spectroscopic data with those of known briarane analogues. Briarenolide $F$ was proven to be the first 6-hydroperoxybriarane derivative and this compound displayed a significant inhibitory effect on the generation of superoxide anion by human neutrophils.
\end{abstract}


Keywords: briarenolide; briarane; Briareum; superoxide anion

\section{Introduction}

Among the diterpenoids isolated from octocorals, the briarane-type metabolites $(3,8$-cyclized cembranes) are a major group of compounds [1-3]. The compounds of this type were suggested to be of marine origin and the octocorals belonging to the genus Briareum have been proven to be the most important source of briarane-type compounds [4-7]. In previous studies, a series of interesting terpenoid derivatives, including briarane [8-35], cembrane [36] and carotenoid [37], had been isolated from the octocorals belonging to the genus Briareum that were distributed in the waters off Taiwan, at the intersection point of the Kuroshio current and the South China Sea surface current. In a continuation of our search for new substances from the Formosan marine invertebrates, the chemical constituents of a specimen octocoral identified as Briareum sp. (Briareidae) were studied. A fraction of its organic extract (fraction $\mathrm{H}$, see Experimental Section) displayed inhibitory effects on the generation of superoxide anion (inhibition rate $36.8 \%$ ) and the release of elastase (inhibition rate $90.3 \%$ ) at a concentration of $10 \mu \mathrm{g} / \mathrm{mL}$. We further isolated two new briarane-type diterpenoids, briarenolides, F (1) and G (2) (Figure 1), from the octocoral Briareum sp. In this paper, we report the isolation, structure determination and bioactivity of briaranes $\mathbf{1}$ and $\mathbf{2}$.

Figure 1. The structures of briarenolides F (1) and G (2).

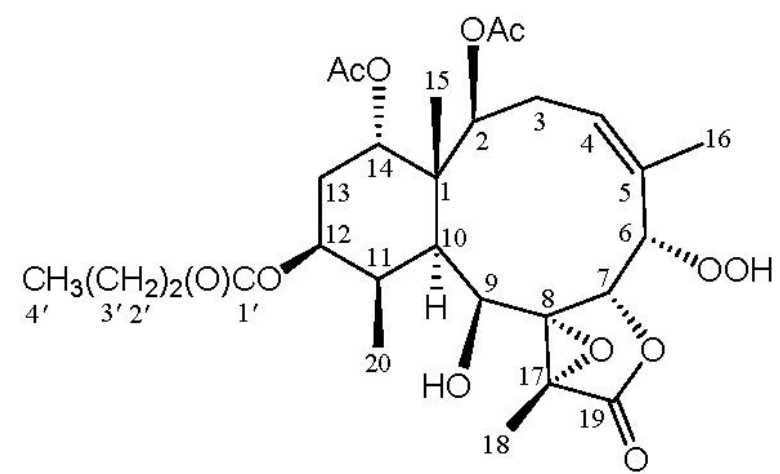

(1)

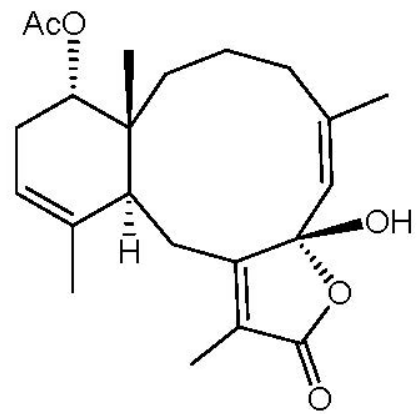

(2)

\section{Results and Discussion}

Briarenolide F (1) was isolated as a white powder. The molecular formula of $\mathbf{1}$ was established as $\mathrm{C}_{28} \mathrm{H}_{40} \mathrm{O}_{12}$ (nine degrees of unsaturation) from a sodium adduct at $m / z 591$ in the ESIMS spectrum and further supported by HRESIMS $\left(\mathrm{C}_{28} \mathrm{H}_{40} \mathrm{O}_{12} \mathrm{Na}, \mathrm{m} / z\right.$ 591.2420, alculated 591.2417). The IR spectrum of 1 showed bands at 3498, 1789 and $1743 \mathrm{~cm}^{-1}$, consistent with the presence of hydroxy, $\gamma$-lactone and ester carbonyl groups. The ${ }^{13} \mathrm{C}$ NMR and DEPT spectra of $\mathbf{1}$ showed that this compound had 28 carbons (Table 1), including seven methyls, four $\mathrm{sp}^{3}$ methylenes, eight $\mathrm{sp}^{3}$ methines, three $\mathrm{sp}^{3}$ quaternary carbons, an $\mathrm{sp}^{2}$ methine and five $\mathrm{sp}^{2}$ quaternary carbons. From the ${ }^{1} \mathrm{H}$ and ${ }^{13} \mathrm{C} \mathrm{NMR}$ spectra (Table 1$), 1$ was found to possess two acetoxy groups $\left(\delta_{\mathrm{H}} 1.99,2.01\right.$, each $3 \mathrm{H} \times \mathrm{s} ; \delta_{\mathrm{C}} 170.6,2 \times \mathrm{qC}$; $\left.21.3,2 \times \mathrm{CH}_{3}\right)$, an $n$-butyrate group $\left(\delta_{\mathrm{H}} 0.94,3 \mathrm{H}, \mathrm{t}, J=7.2 \mathrm{~Hz} ; 1.63,2 \mathrm{H}\right.$, sext, $J=7.2 \mathrm{~Hz} ; 2.27,2 \mathrm{H}$, 
t, $\left.J=7.2 \mathrm{~Hz} ; \delta_{\mathrm{C}} 13.7, \mathrm{CH}_{3} ; 18.4, \mathrm{CH}_{2} ; 36.3, \mathrm{CH}_{2} ; 173.1, \mathrm{qC}\right)$, a $\gamma$-lactone moiety $\left(\delta_{\mathrm{C}} 171.0, \mathrm{qC}-19\right)$ and a trisubstituted olefin $\left(\delta_{\mathrm{H}} 5.65,1 \mathrm{H}\right.$, br d, $\left.J=13.6 \mathrm{~Hz}, \mathrm{H}-4 ; \delta_{\mathrm{C}} 130.3, \mathrm{CH}-4 ; 128.8, \mathrm{qC}-5\right)$. The presence of a tetrasubstituted epoxide containing a methyl substituent was established from the signals of two quaternary oxygenated carbons at $\delta_{\mathrm{C}} 68.8(\mathrm{qC}-8)$ and $58.4(\mathrm{qC}-17)$ and further confirmed by the proton signal of a methyl singlet at $\delta_{\mathrm{H}} 1.49\left(3 \mathrm{H}, \mathrm{s}, \mathrm{H}_{3}-18\right)$. Thus, from the above NMR data, five degrees of unsaturation were accounted for and $\mathbf{1}$ was identified as a tetracyclic compound.

Table 1. ${ }^{1} \mathrm{H}\left(400 \mathrm{MHz}, \mathrm{CDCl}_{3}\right)$ and ${ }^{13} \mathrm{C}\left(100 \mathrm{MHz}, \mathrm{CDCl}_{3}\right) \mathrm{NMR}$ data, ${ }^{1} \mathrm{H}-{ }^{1} \mathrm{H}$ COSY and HMBC correlations for briarane $\mathbf{1}$.

\begin{tabular}{|c|c|c|c|c|}
\hline $\mathrm{C} / \mathrm{H}$ & $\delta \quad(J$ in $\mathrm{Hz})$ & $\delta_{\mathrm{C},}$, Mult. & ${ }^{1} \mathrm{H}-{ }^{1} \mathrm{H} \mathrm{COSY}$ & HMBC $(\mathrm{H} \rightarrow \mathrm{C})$ \\
\hline 1 & & $44.9, \mathrm{qC}$ & & \\
\hline 2 & $5.22 \mathrm{~d}(8.0)$ & 75.4, $\mathrm{CH}$ & $\mathrm{H}_{2}-3$ & $\begin{array}{l}\mathrm{C}-1,-4,-10,-15, \\
\text { acetate carbonyl }\end{array}$ \\
\hline $3 \alpha$ & $1.89 \mathrm{~m}$ & $33.3, \mathrm{CH}_{2}$ & $\mathrm{H}-2, \mathrm{H}-3 \beta, \mathrm{H}-4$ & N.O. \\
\hline$\beta$ & $3.81 \mathrm{dd}(17.2,13.6)$ & & H-2, H-3 $\alpha, H-4$ & $C-4,-5$ \\
\hline 4 & 5.65 br d (13.6) & $130.3, \mathrm{CH}$ & $\mathrm{H}_{2}-3, \mathrm{H}_{3}-16$ & N.O. \\
\hline 5 & & $128.8, \mathrm{qC}$ & & \\
\hline 6 & $4.65 \mathrm{~d}(2.4)$ & $84.9, \mathrm{CH}$ & $\mathrm{H}-7$ & $C-4,-5,-7,-8,-16$ \\
\hline 7 & $5.33 \mathrm{~d}(2.4)$ & $77.2, \mathrm{CH}$ & H-6 & $C-5,-6$ \\
\hline 8 & & $68.8, \mathrm{qC}$ & & \\
\hline 9 & $4.59 \mathrm{~d}(4.8)$ & $75.1, \mathrm{CH}$ & $\mathrm{OH}-9$ & $C-1,-8,-10,-11,-17$ \\
\hline 10 & $2.06 \mathrm{~d}(4.0)$ & $39.4, \mathrm{CH}$ & $\mathrm{H}-11$ & $C-1,-8,-9,-15,-20$ \\
\hline 11 & $2.28 \mathrm{~m}$ & $40.2, \mathrm{CH}$ & $\mathrm{H}-10, \mathrm{H}-12, \mathrm{H}_{3}-20$ & $C-1,-10,-12$ \\
\hline 12 & $4.98 \mathrm{ddd}(12.4,5.2,5.2)$ & $70.7, \mathrm{CH}$ & $\mathrm{H}-11, \mathrm{H}_{2}-13$ & C-20, $n$-butyrate carbonyl \\
\hline 13 & $1.87-1.97 \mathrm{~m}$ & $26.5, \mathrm{CH}_{2}$ & $\mathrm{H}-12, \mathrm{H}-14$ & $\mathrm{C}-12$ \\
\hline 14 & $4.88 \mathrm{dd}(3.2,2.4)$ & $74.9, \mathrm{CH}$ & $\mathrm{H}_{2}-13$ & N.O. \\
\hline 15 & $1.37 \mathrm{~s}$ & $15.9, \mathrm{CH}_{3}$ & & $C-1,-2,-10,-14$ \\
\hline 16 & 1.77 br s & $25.4, \mathrm{CH}_{3}$ & $\mathrm{H}-4$ & $C-4,-5,-6$ \\
\hline 17 & & $58.4, \mathrm{qC}$ & & \\
\hline 18 & $1.49 \mathrm{~s}$ & $8.8, \mathrm{CH}_{3}$ & & C-8, $-17,-19$ \\
\hline 19 & & 171.0, qC & & \\
\hline 20 & $1.22 \mathrm{~d}(7.2)$ & $10.6, \mathrm{CH}_{3}$ & $\mathrm{H}-11$ & $C-10,-11,-12$ \\
\hline \multirow[t]{2}{*}{ 2-OAc } & & 170.6, qC & & \\
\hline & $1.99 \mathrm{~s}$ & 21.3, $\mathrm{CH}_{3}$ & & Acetate carbonyl \\
\hline 6-OOH & 8.71 br s & & & N.O. \\
\hline 9-OH & $2.95 \mathrm{~d}(4.8)$ & & H-9 & N.O. \\
\hline \multirow[t]{4}{*}{ 12-OC(O)Pr } & & 173.1, qC & & \\
\hline & $2.27 \mathrm{t}(7.2)$ & $36.3, \mathrm{CH}_{2}$ & $\mathrm{H}_{2}-3^{\prime}$ & $C-1^{\prime},-3^{\prime},-4^{\prime}$ \\
\hline & $1.63 \operatorname{sext}(7.2)$ & $18.4, \mathrm{CH}_{2}$ & $\mathrm{H}_{2}-2^{\prime}, \mathrm{H}_{3}-4^{\prime}$ & $C-1^{\prime},-2^{\prime},-4^{\prime}$ \\
\hline & 0.94 t (7.2) & $13.7, \mathrm{CH}_{3}$ & $\mathrm{H}_{2}-3^{\prime}$ & $C-2^{\prime},-3^{\prime}$ \\
\hline \multirow[t]{2}{*}{ 14-OAc } & & $170.6, \mathrm{qC}$ & & \\
\hline & $2.01 \mathrm{~s}$ & $21.3, \mathrm{CH}_{3}$ & & Acetate carbonyl \\
\hline
\end{tabular}

N.O. $=$ Not observed.

${ }^{1} \mathrm{H}-{ }^{1} \mathrm{H}$ couplings in the COSY spectrum of 1 enabled identification of the $\mathrm{C}-2 /-3 /-4, \mathrm{C}-6 /-7$, C-10/-11/-12/-13/-14, C-4/-16 (by allylic coupling) and C-11/-20 units (Table 1), which were 
assembled with the assistance of an $\mathrm{HMBC}$ experiment. The HMBC correlations between protons and quaternary carbons of 1, such as H-2, H-9, H-10, H-11, H3-15/C-1; H-3 $\beta$, H-6, H-7, H3-16/C-5; H-6, $\mathrm{H}-9, \mathrm{H}-10, \mathrm{H}_{3}-18 / \mathrm{C}-8$; H-9, $\mathrm{H}_{3}-18 / \mathrm{C}-17$; and $\mathrm{H}_{3}-18 / \mathrm{C}-19$, permitted the elucidation of the carbon skeleton (Table 1). The vinyl methyl at C-5 was confirmed by the allylic coupling between $\mathrm{H}-4 / \mathrm{H}_{3}-16$ in the ${ }^{1} \mathrm{H}-{ }^{1} \mathrm{H}$ COSY spectrum and by the HMBC correlations between $\mathrm{H}_{3}-16 / \mathrm{C}-4,-5,-6$ and H-6/C-16. The ring junction $\mathrm{C}-15$ methyl group was positioned at $\mathrm{C}-1$ from the $\mathrm{HMBC}$ correlations between $\mathrm{H}_{3}-15 / \mathrm{C}-1,-2,-10,-14 ; \mathrm{H}-2 / \mathrm{C}-15$; and $\mathrm{H}-10 / \mathrm{C}-15$. In addition, the carbon signal at $\delta_{\mathrm{C}} 173.1$ (qC) was correlated with the signal of the methylene protons at $\delta_{\mathrm{H}} 2.27$ in the HMBC spectrum and was consequently assigned as the carbon atom of the $n$-butyrate carbonyl. Additionally, the $n$-butyrate positioned at C-12 was confirmed by the connectivity between $\mathrm{H}-12\left(\delta_{\mathrm{H}} 4.98\right)$ and the carbonyl carbon $\left(\delta_{\mathrm{C}} 173.1, \mathrm{qC}\right)$ of the $n$-butyrate. Furthermore, an acetate ester at $\mathrm{C}-2$ was established by a correlation between $\mathrm{H}-2\left(\delta_{\mathrm{H}} 5.22\right)$ and the acetate carbonyl $\left(\delta_{\mathrm{C}} 170.6, \mathrm{qC}\right)$ observed in the HMBC spectrum of 1. The presence of a hydroxy group at $\mathrm{C}-9$ was deduced from the ${ }^{1} \mathrm{H}-{ }^{1} \mathrm{H}$ COSY correlation between a hydroxy proton $\left(\delta_{\mathrm{H}} 2.95\right)$ and $\mathrm{H}-9\left(\delta_{\mathrm{H}} 4.59\right)$. The presence of a hydroperoxy group in 1 was supported by a hydroperoxy proton signal at $\delta_{\mathrm{H}} 8.71$ as a broad signlet [22,32,38]. Due to absence of HMBC correlations for $\mathrm{H}-14\left(\delta_{\mathrm{H}} 4.88\right)$ and the hydroperoxy proton $\left(\delta_{\mathrm{H}} 8.71\right)$, the positions for the remaining acetoxy and hydroperoxy groups could not be determined by this method. By comparison the ${ }^{1} \mathrm{H}$ and ${ }^{13} \mathrm{C}$ NMR data of C-14 oxymethine for $1\left(\delta_{\mathrm{H}} 4.88 ; \delta_{\mathrm{C}} 74.9\right)$ with those of a known briarane analogue, excavatolide $\mathrm{F}(3)\left(\delta_{\mathrm{H}} 4.94 ; \delta_{\mathrm{C}} 74.1\right)$ (Figure 2$)$ [10], which possesses a similar cyclohexane moiety as that of $\mathbf{1}$, the remaining acetoxy group in $\mathbf{1}$ was placed at $\mathrm{C}-14$. Thus, the hydroperoxy group is positioned at C-6, an oxymethine at $\delta_{\mathrm{C}} 84.9(\mathrm{CH})$, by analysis of the ${ }^{1} \mathrm{H}-{ }^{1} \mathrm{H}$ COSY correlations and characteristic NMR signal analysis.

Figure 2. The structures of briarenolide F (1) and excavatolide F (3).

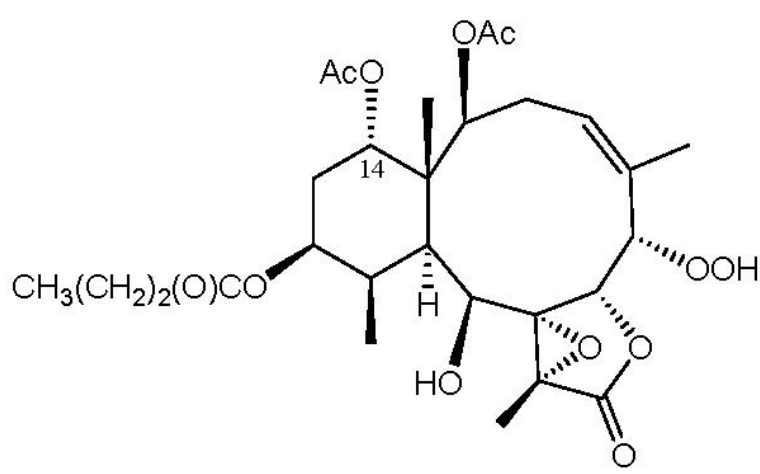

(1)

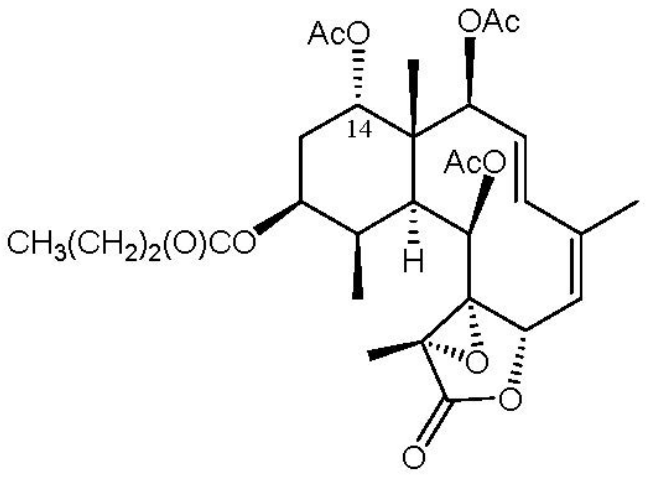

(3)

In all naturally-occurring briaranes, H-10 is trans to the C-15 methyl group, and these two groups are assigned as $\alpha$ - and $\beta$-oriented in most briarane derivatives [4-7]. The relative configuration of 1 was elucidated from the interactions observed in a NOESY experiment and was found to be compatible with that of 1 offered by computer modeling (Figure 3) [39] and that obtained from vicinal proton coupling constant analysis. In the NOESY experiment of 1, the correlations of H-10 with H-2, $\mathrm{H}-9, \mathrm{H}-11$ and $\mathrm{H}-12$, but not with $\mathrm{H}_{3}-15$ and $\mathrm{H}_{3}-20$, indicated that these protons $(\mathrm{H}-2, \mathrm{H}-9, \mathrm{H}-10, \mathrm{H}-11$ and $\mathrm{H}-12$ ) were situated on the same face, and these were assigned as $\alpha$ protons, since the $\mathrm{C}-15$ and 
C-20 methyls are $\beta$-substituents at $\mathrm{C}-1$ and $\mathrm{C}-11$, respectively. $\mathrm{H}-14$ was found to exhibit an interaction with $\mathrm{H}_{3}-15$, but not with $\mathrm{H}-10$, revealing the $\beta$-orientation of this proton. The configuration at C-9 is worthy of comment. H-9 was found to exhibit correlations with H-10, H-11, $\mathrm{H}_{3}-18$ and $\mathrm{H}_{3}-20$. From a consideration of molecular models, $\mathrm{H}-9$ was found to be reasonably close to $\mathrm{H}-10, \mathrm{H}-11, \mathrm{H}_{3}-18$ and $\mathrm{H}_{3}-20$, while it was placed on the $\alpha$ face in $\mathbf{1}$. The $\mathrm{C}-16$ vinyl methyl showed correlations with $\mathrm{H}-4$ and H-6, demonstrating the $Z$ configuration of $\Delta^{4,5}$ and the hydroperoxy group at C- 6 was $\alpha$-oriented. The cis relationship between H-6 and H-7 was established by a correlation between H-6 and H-7 and a small coupling constant $(J=2.4 \mathrm{~Hz})$ between these two protons. Moreover, an acetyl methyl $\left(\delta_{\mathrm{H}} 2.01\right)$ exhibited correlations with H-12 and H-2, further supporting an acetoxy group was positioned on the $\alpha$-position at C-14 in $\mathbf{1}$. Based on the above findings, the configurations of all chiral carbons of 1 were assigned as $1 S^{*}, 2 S^{*}, 6 S^{*}, 7 S^{*}, 8 R^{*}, 9 S^{*}, 10 S^{*}, 11 R^{*}, 12 S^{*}, 14 S^{*}, 17 R^{*}$, and the structure of 1 was established unambiguously. To the best of our knowledge, briarane derivatives possessing a hydroperoxy group are rarely found [22,32,38] and briarenolide F (1) is the first briarane derivative possessing a 6-hydroperoxy group. A double bond positioned at C-4(5) in briarane-type metabolites is also rarely found $[31,40-42]$.

Figure 3. The stereoview of $\mathbf{1}$ (generated from computer modeling) and the calculated distances $(\AA)$ between selected protons with key NOESY correlations.

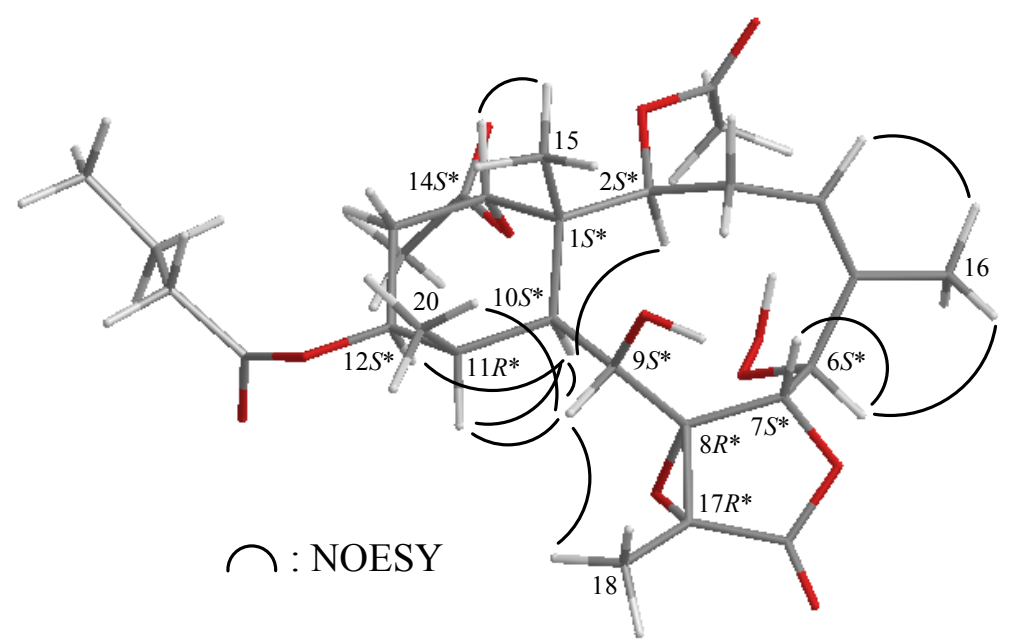

$\begin{array}{ll}\mathrm{H} / \mathrm{H} & (\AA) \\ \mathrm{H}-2 / \mathrm{H}-10 & 2.36 \\ \mathrm{H}-4 / \mathrm{H}_{3}-16 & 2.25 \\ \mathrm{H}-6 / \mathrm{H}-7 & 2.92 \\ \mathrm{H}-6 / \mathrm{H}_{3}-16 & 2.25 \\ \mathrm{H}-9 / \mathrm{H}-10 & 2.75 \\ \mathrm{H}-9 / \mathrm{H}-11 & 2.18 \\ \mathrm{H}-9 / \mathrm{H}_{3}-18 & 2.24 \\ \mathrm{H}-9 / \mathrm{H}_{3}-20 & 2.36 \\ \mathrm{H}-10 / \mathrm{H}-11 & 2.38 \\ \mathrm{H}-10 / \mathrm{H}-12 & 2.56 \\ \mathrm{H}-14 / \mathrm{H}_{3}-15 & 2.37\end{array}$

Briarenolide G (2) was isolated as a white powder whose HRESIMS showed a molecular ion at $m / z 397.1989$ implying that $\mathbf{2}$ had the molecular formula $\mathrm{C}_{22} \mathrm{H}_{30} \mathrm{O}_{5}\left(\mathrm{C}_{22} \mathrm{H}_{30} \mathrm{O}_{5} \mathrm{Na}\right.$, calculated 397.1991). The IR spectrum revealed absorptions for hydroxy $\left(3397 \mathrm{~cm}^{-1}\right)$ and ester carbonyl $\left(1757\right.$ and $\left.1734 \mathrm{~cm}^{-1}\right)$ groups. The ${ }^{1} \mathrm{H}$ NMR data (Table 2$)$ showed resonances due to an acetyl methyl $\left(\delta_{\mathrm{H}} 2.03,3 \mathrm{H}, \mathrm{s}\right)$, three vinyl methyls $\left(\delta_{\mathrm{H}} 1.78,3 \mathrm{H}\right.$, br s, $\left.\mathrm{H}_{3}-16 ; 1.87,3 \mathrm{H}, \mathrm{d}, J=1.6 \mathrm{~Hz}, \mathrm{H}_{3}-18 ; 1.63,3 \mathrm{H}, \mathrm{d}, J=0.8 \mathrm{~Hz}, \mathrm{H}_{3}-20\right)$, a quaternary methyl $\left(\delta_{\mathrm{H}} 0.77,3 \mathrm{H}, \mathrm{s}, \mathrm{H}_{3}-15\right)$, two olefinic protons $\left(\delta_{\mathrm{H}} 5.29,1 \mathrm{H}\right.$, br s, H-6; 5.12, $1 \mathrm{H}, \mathrm{m}$, $\mathrm{H}-12)$ and an oxymethine signal $\left(\delta_{\mathrm{H}} 4.78,1 \mathrm{H}\right.$, br s, H-14). The ${ }^{13} \mathrm{C}$ NMR and DEPT spectra of 2 (Table 2) revealed the presence of a tetrasubstituted $\left(\delta_{\mathrm{C}} 160.8, \mathrm{qC}-8 ; 125.1, \mathrm{qC}-17\right)$ and two trisubstituted $\left(\delta_{\mathrm{C}} 144.4\right.$, qC-5; 124.6, CH-6; 136.3, qC-11; 117.8, CH-12) carbon-carbon double bonds, a hemiketal carbon $\left(\delta_{\mathrm{C}} 106.7, \mathrm{qC}-7\right)$, an acetate carbonyl $\left(\delta_{\mathrm{C}} 170.9, \mathrm{qC}\right)$, an $\alpha, \beta$-unsaturated- $\gamma$-lactone carbonyl $\left(\delta_{\mathrm{C}} 171.1, \mathrm{qC}-19\right)$, a tetrasubstituted carbon atom bearing a carbon substituent $\left(\delta_{\mathrm{C}} 39.1, \mathrm{qC}-1\right)$ and an oxymethine $\left(\delta_{\mathrm{C}} 77.2, \mathrm{CH}-14\right)$. 
Table 2. ${ }^{1} \mathrm{H}\left(400 \mathrm{MHz}, \mathrm{CDCl}_{3}\right)$ and ${ }^{13} \mathrm{C}\left(100 \mathrm{MHz}, \mathrm{CDCl}_{3}\right) \mathrm{NMR}$ data, ${ }^{1} \mathrm{H}-{ }^{1} \mathrm{H}$ COSY and HMBC correlations for briarane 2.

\begin{tabular}{|c|c|c|c|c|}
\hline $\mathrm{C} / \mathrm{H}$ & $\delta_{\mathrm{H}}(J$ in $\mathrm{Hz})$ & $\delta_{\mathrm{C}}$, Mult. & ${ }^{1} \mathrm{H}-{ }^{1} \mathrm{H} \mathrm{COSY}$ & HMBC $(\mathrm{H} \rightarrow \mathrm{C})$ \\
\hline 1 & & $39.1, \mathrm{qC}$ & & \\
\hline $2 \alpha$ & $1.69 \mathrm{~m}$ & $35.4, \mathrm{CH}_{2}$ & $\mathrm{H}-2 \beta, \mathrm{H}_{2}-3$ & $C-3,-14$ \\
\hline$\beta$ & $1.29 \mathrm{~m}$ & & $\mathrm{H}-2 \alpha, \mathrm{H}_{2}-3$ & $C-1,-3,-10,-14$ \\
\hline 3 & $1.72 \mathrm{~m}$ & $23.7, \mathrm{CH}_{2}$ & $\mathrm{H}_{2}-2, \mathrm{H}_{2}-4$ & $\mathrm{C}-2$ \\
\hline $4 \alpha$ & $1.90 \mathrm{~m}$ & $29.6, \mathrm{CH}_{2}$ & $\mathrm{H}_{2}-3, \mathrm{H}-4 \beta$ & N.O. \\
\hline$\beta$ & $3.72 \mathrm{~m}$ & & $\mathrm{H}_{2}-3, \mathrm{H}-4 \alpha$ & $C-3,-16$ \\
\hline 5 & & $144.4, \mathrm{qC}$ & & \\
\hline 6 & $5.29 \mathrm{br} \mathrm{s}$ & $124.6, \mathrm{CH}$ & $\mathrm{H}_{3}-16$ & $C-4,-7,-16$ \\
\hline 7 & & $106.7, \mathrm{qC}$ & & \\
\hline 8 & & $160.8, \mathrm{qC}$ & & \\
\hline $9 \alpha$ & 2.54 br d (15.2) & 25.3, $\mathrm{CH}_{2}$ & $\mathrm{H}-9 \beta, \mathrm{H}-10$ & C-8, $-10,-11,-17$ \\
\hline$\beta$ & $2.37 \mathrm{dd}(15.2,10.8)$ & & $\mathrm{H}-9 \alpha, \mathrm{H}-10$ & $C-7,-8,-10,-11,-17$ \\
\hline 10 & $3.76 \mathrm{~d}(10.8)$ & $35.9, \mathrm{CH}$ & $\mathrm{H}_{2}-9$ & N.O. \\
\hline 11 & & $136.3, \mathrm{qC}$ & & \\
\hline 12 & $5.12 \mathrm{~m}$ & $117.8, \mathrm{CH}$ & $\mathrm{H}_{2}-13, \mathrm{H}_{3}-20$ & N.O. \\
\hline $13 \alpha$ & $2.06 \mathrm{~m}$ & 29.3, $\mathrm{CH}_{2}$ & $\mathrm{H}-12, \mathrm{H}-13 \beta$ & $\mathrm{C}-11,-12,-14$ \\
\hline$\beta$ & $2.33 \mathrm{~m}$ & & H-12, H-13 $\alpha$ & $\mathrm{C}-11$ \\
\hline 14 & 4.78 br s & 77.2, $\mathrm{CH}$ & $\mathrm{H}_{2}-13$ & $\mathrm{C}-12$ \\
\hline 15 & $0.77 \mathrm{~s}$ & $21.9, \mathrm{CH}_{3}$ & & $C-1,-2,-10,-14$ \\
\hline 16 & $1.78 \mathrm{br} \mathrm{s}$ & $23.9, \mathrm{CH}_{3}$ & H-6 & $C-4,-5,-6$ \\
\hline 17 & & $125.1, \mathrm{qC}$ & & \\
\hline 18 & $1.87 \mathrm{~d}(1.6)$ & 9.1, $\mathrm{CH}_{3}$ & & $C-8,-17,-19$ \\
\hline 19 & & $171.7, \mathrm{qC}$ & & \\
\hline 20 & $1.63 \mathrm{~d}(0.8)$ & $21.9, \mathrm{CH}_{3}$ & $\mathrm{H}-12$ & $\mathrm{C}-10,-11,-12$ \\
\hline 7-OH & $3.35 \mathrm{~s}$ & & & $C-6,-7,-8$ \\
\hline \multirow[t]{2}{*}{ 14-OAc } & & $170.9, \mathrm{qC}$ & & \\
\hline & $2.03 \mathrm{~s}$ & $21.7, \mathrm{CH}_{3}$ & & Acetate carbonyl \\
\hline
\end{tabular}

N.O. $=$ Not observed.

From the ${ }^{1} \mathrm{H}-{ }^{1} \mathrm{H}$ COSY experiment of 2 (Table 2), it was possible to establish the separate spin systems that map out the proton sequences from $\mathrm{H}_{2}-2 / \mathrm{H}_{2}-3 / \mathrm{H}_{2}-4$ and $\mathrm{H}_{2}-9 / \mathrm{H}-10$. These data, together with the HMBC correlations between $\mathrm{H}_{2}-2 / \mathrm{C}-1,-3,-10 ; \mathrm{H}_{2}-3 / \mathrm{C}-2 ; \mathrm{H}-4 \beta / \mathrm{C}-3 ; \mathrm{H}-6 / \mathrm{C}-4$, -7; and $\mathrm{H}_{2}-9 / \mathrm{C}-7,-8,-10$, established the connectivity from $\mathrm{C}-1$ to $\mathrm{C}-10$ in the ten-membered ring (Table 2). The vinyl methyl at $\mathrm{C}-5$ was confirmed by the $\mathrm{HMBC}$ correlations between $\mathrm{H}_{3}-16 / \mathrm{C}-4,-5$, -6 ; $\mathrm{H}-4 \beta / \mathrm{C}-16$; and $\mathrm{H}-6 / \mathrm{C}-16$, and further supported by the allylic coupling between $\mathrm{H}-6$ and $\mathrm{H}_{3}-16$. The methylcyclohexene ring, which is fused to the ten-membered ring at $\mathrm{C}-1$ and $\mathrm{C}-10$, was elucidated by the ${ }^{1} \mathrm{H}-{ }^{1} \mathrm{H}$ COSY correlations between $\mathrm{H}-12 / \mathrm{H}_{2}-13 / \mathrm{H}-14$ and $\mathrm{H}-12 / \mathrm{H}_{3}-20$ (by allylic coupling) and by the HMBC correlations between $\mathrm{H}_{2}-2 / \mathrm{C}-14, \mathrm{H}_{2}-9 / \mathrm{C}-11$ and $\mathrm{H}_{3}-20 / \mathrm{C}-10,-11,-12$. The ring junction $\mathrm{C}-15$ methyl group was positioned at $\mathrm{C}-1$ from the $\mathrm{HMBC}$ correlations between $\mathrm{H}_{3}-15 / \mathrm{C}-1,-2,-10,-14$. In addition, the acetate ester at C-14 was established by a correlation between $\mathrm{H}-14\left(\delta_{\mathrm{H}} 4.78\right)$ and the acetate carbonyl observed in the HMBC spectrum of 2. The presence of a hydroxy group at C-7 was deduced from the HMBC correlations between the hydroxy proton $\left(\delta_{\mathrm{H}} 3.35,1 \mathrm{H}, \mathrm{s}, \mathrm{OH}-7\right)$ and C-6, C-7, 
and C-8. The C-7 hydroxy group was concluded to be a part of hemiketal constellation on the basis of a characteristic carbon signal at $\delta_{\mathrm{C}} 106.7$ (a quaternary hemiketal carbon, qC-7). These data, together with the HMBC correlations between $\mathrm{H}_{3}-18 / \mathrm{C}-8,-17$, -19 , were used to establish the molecular framework of 2.

NOESY measurements were carried out in order to deduce the relative stereochemical features of 2 (Figure 4). Thus, $\mathrm{H}_{3}-15$ gave a correlation with $\mathrm{H}-14$, but not with $\mathrm{H}-10$, indicating that $\mathrm{H}_{3}-15$ and $\mathrm{H}-14$ are located on the same face (assigned as the $\beta$-face) and that $\mathrm{H}-10$ lies on the opposite side, $\alpha$-face. The NOESY spectrum showed correlations between $\mathrm{H}-6 / \mathrm{H}_{3}-16$ and $\mathrm{H}-12 / \mathrm{H}_{3}-20$, revealing the $Z$ geometry of the C-5/6 and C-11/12 double bonds in 2. Due to the absence of NOESY correlations for the C-7 hydroxy group, the configuration at that chiral center could not be determined by this method. By comparison of the ${ }^{13} \mathrm{C}$ NMR chemical shifts of C-6 $\left(\delta_{\mathrm{C}} 124.6\right), \mathrm{C}-7\left(\delta_{\mathrm{C}} 106.7\right)$ and C-8 $\left(\delta_{\mathrm{C}} 160.8\right)$ for 2 with those of an unnamed known $7 \beta$-hydroxybriarane analogue $4\left(\delta_{\mathrm{C}} 124.8\right.$, C-6; 106.2, C-7, 160.1, C-8), which was obtained from a Caribbean octocoral Briareum polyanthes [43] (Figure 5), we deduced that the C-7 hydroxy group was $\beta$-oriented and the configuration of all the chiral carbons in 2 were assigned as $1 R^{*}, 7 S^{*}, 10 S^{*}, 14 S^{*}$.

Figure 4. The stereoview of $\mathbf{2}$ (generated from computer modeling) and the calculated distances $(\AA)$ between selected protons with key NOESY correlations.

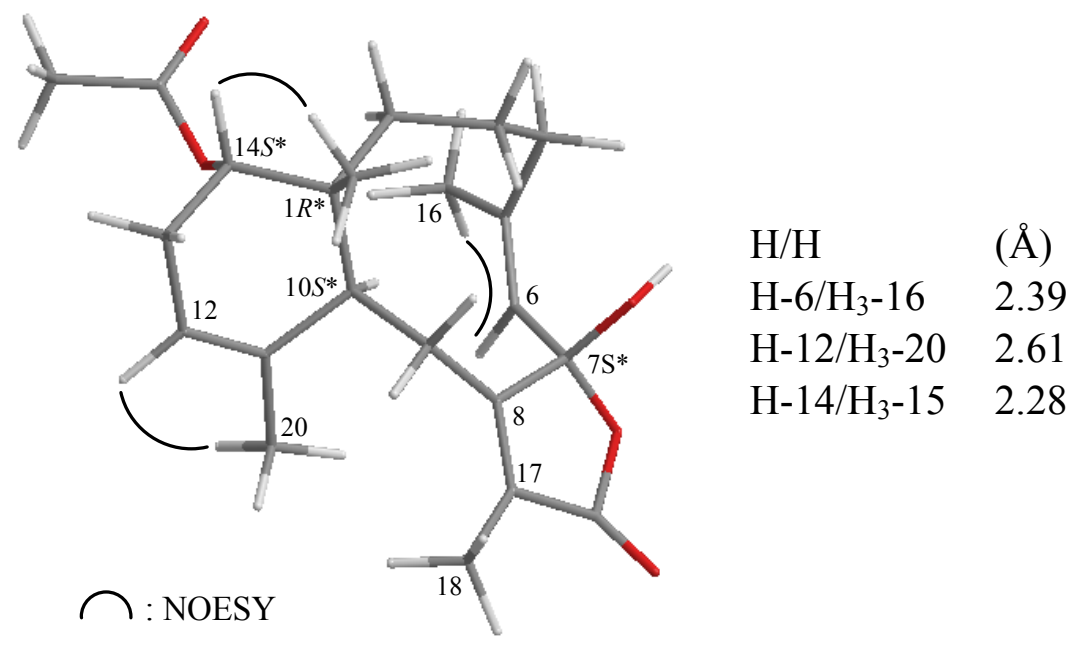

Figure 5. The structures of briarenolide G (2) and briarane (4).

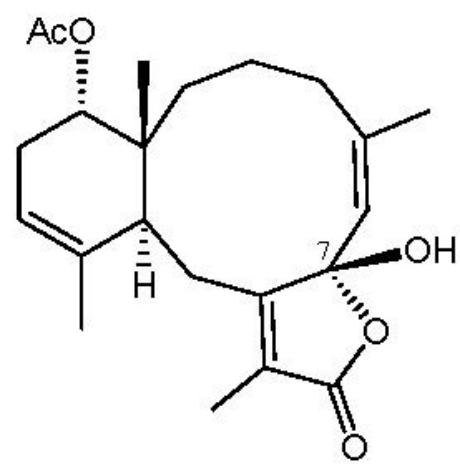

(2)

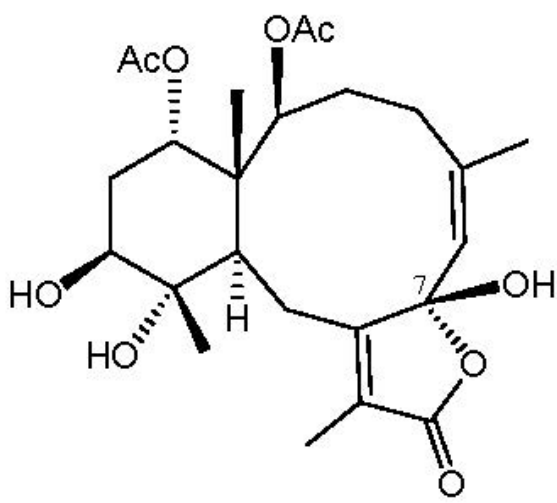

(4) 
The in vitro anti-inflammatory effects of briaranes $\mathbf{1}$ and $\mathbf{2}$ were tested. Briarenolide F (1) was found to display a significant inhibitory effect on the generation of superoxide anion by human neutrophils (Table 3).

Table 3. Inhibitory effects of briaranes $\mathbf{1}$ and $\mathbf{2}$ on the generation of superoxide anion and the release of elastase by human neutrophils in response to FMLP/CB.

\begin{tabular}{|c|c|c|c|c|}
\hline \multirow[b]{2}{*}{ Compounds } & \multicolumn{2}{|c|}{ Superoxide Anion } & \multicolumn{2}{|c|}{ Elastase Release } \\
\hline & $\mathrm{IC}_{50}(\mu \mathrm{g} / \mathrm{mL})$ & Inh\% $^{a}$ & $\mathrm{IC}_{50}(\mu \mathrm{g} / \mathrm{mL})$ & $\operatorname{Inh}^{a}{ }^{a}$ \\
\hline 1 & $3.82 \pm 0.45$ & $76.65 \pm 4.21$ & $>10.0$ & $27.48 \pm 6.60$ \\
\hline 2 & $>10.0$ & $22.04 \pm 3.43$ & $>10.0$ & $12.98 \pm 4.68$ \\
\hline DPI $^{b}$ & $0.82 \pm 0.31$ & & & \\
\hline Elastatinal $^{b}$ & & & $31.82 \pm 5.92$ & \\
\hline
\end{tabular}

\section{Experimental Section}

\subsection{General Experimental Procedures}

Optical rotations were measured on a Jasco P-1010 digital polarimeter. Infrared spectra were recorded on a Varian Diglab FTS 1000 FT-IR spectrometer; peaks are reported in $\mathrm{cm}^{-1}$. The NMR spectra were recorded on a Varian Mercury Plus 400 NMR spectrometer. Coupling constants $(J)$ are given in $\mathrm{Hz} .{ }^{1} \mathrm{H}$ and ${ }^{13} \mathrm{C}$ NMR assignments were supported by ${ }^{1} \mathrm{H}-{ }^{1} \mathrm{H}$ COSY, HMQC, HMBC and NOESY experiments. ESIMS and HRESIMS were recorded on a Bruker APEX II mass spectrometer. Column chromatography was performed on silica gel (230-400 mesh, Merck, Darmstadt, Germany). TLC was carried out on precoated Kieselgel $60 \mathrm{~F}_{254}(0.25 \mathrm{~mm}$, Merck), and spots were visualized by spraying with $10 \% \mathrm{H}_{2} \mathrm{SO}_{4}$ solution followed by heating. HPLC was performed using a system comprised of a Hitachi L-7100 pump and a Rheodyne injection port. A normal phase column (Hibar $250 \times 10 \mathrm{~mm}$, Merck, silica gel 60, $5 \mu \mathrm{m}$ ) was used for HPLC.

\subsection{Animal Material}

Specimens of the octocorals Briareum sp. were collected by hand using scuba equipment off the coast of southern Taiwan in July 2011 and stored in a freezer until extraction. A voucher specimen (NMMBA-TW-SC-2011-77) was deposited in the National Museum of Marine Biology and Aquarium. This organism was identified by comparison with previous descriptions [44-47].

\subsection{Extraction and Isolation}

Sliced bodies of Briareum sp. (wet weight $6.32 \mathrm{~kg}$, dry weight $2.78 \mathrm{~kg}$ ) were extracted with a mixture of methanol $(\mathrm{MeOH})$ and dichloromethane (DCM) (1:1). The extract was partitioned between ethyl acetate (EtOAc) and $\mathrm{H}_{2} \mathrm{O}$. The EtOAc layer was separated on silica gel and eluted using $n$-hexane/EtOAc (stepwise, 100:1-pure EtOAc) to yield 18 fractions A-R. Fraction $\mathrm{H}$ was chromatographed on silica gel and eluted using $n$-hexane/acetone (stepwise, 40:1-pure acetone) to 
afford 45 fractions H1-H45. Fraction H11 was separated by normal-phase HPLC (NP-HPLC) using a mixture of $n$-hexane and EtOAc $(5: 2)$ as the mobile phase to afford compound $2(0.4 \mathrm{mg})$. Fraction H16 was further purified by normal-phase HPLC using a mixture of $n$-hexane and acetone as the mobile phase (7:2) to afford compound 1 ( $2.3 \mathrm{mg})$.

Briarenolide F (1): white powder; mp $141-142{ }^{\circ} \mathrm{C}$; $[\alpha]_{\mathrm{D}}^{25}+32\left(c 0.1, \mathrm{CHCl}_{3}\right)$; IR (neat) $v_{\max } 3498$, 1789, $1743 \mathrm{~cm}^{-1} ;{ }^{1} \mathrm{H}\left(\mathrm{CDCl}_{3}, 400 \mathrm{MHz}\right)$ and ${ }^{13} \mathrm{C}\left(\mathrm{CDCl}_{3}, 100 \mathrm{MHz}\right) \mathrm{NMR}$ data, see Table 1; ESIMS: $m / z 591[\mathrm{M}+\mathrm{Na}]^{+}$; HRESIMS: $m / z 591.2420$ (calcd for $\mathrm{C}_{28} \mathrm{H}_{40} \mathrm{O}_{12} \mathrm{Na}, 591.2417$ ).

Briarenolide G (2): white powder; mp 78-80 ${ }^{\circ} \mathrm{C}$; $[\alpha]_{\mathrm{D}}^{25}-97\left(c 0.02, \mathrm{CHCl}_{3}\right)$; IR (neat) v $v_{\max } 3397$, 1757, $1734 \mathrm{~cm}^{-1}$; ${ }^{1} \mathrm{H}\left(\mathrm{CDCl}_{3}, 400 \mathrm{MHz}\right)$ and ${ }^{13} \mathrm{C}\left(\mathrm{CDCl}_{3}, 100 \mathrm{MHz}\right)$ NMR data, see Table 2; ESIMS: $m / z 397[\mathrm{M}+\mathrm{Na}]^{+}$; HRESIMS: $\mathrm{m} / z 397.1989$ (calcd for $\mathrm{C}_{22} \mathrm{H}_{30} \mathrm{O}_{5} \mathrm{Na}, 397.1991$ ).

\subsection{Molecular Mechanics Calculations}

Implementation of the MM2 force field [39] in CHEM3D PRO software from CambridgeSoft Corporation (version 9.0, Cambridge, MA, USA; 2005) was used to calculate the molecular models.

\subsection{Superoxide Anion Generation and Elastase Release by Human Neutrophils}

Human neutrophils were obtained by means of dextran sedimentation and Ficoll centrifugation. Measurements of superoxide anion generation and elastase release were carried out according to previously described procedures [48,49]. Briefly, superoxide anion production was assayed by monitoring the superoxide dismutase-inhibitable reduction of ferricytochrome $c$. Elastase release experiments were performed using MeO-Suc-Ala-Ala-Pro-Valp-nitroanilide as the elastase substrate.

\section{Conclusions}

Briarane-type natural products (3,8-cyclized cembranoid) were found in various marine organisms, particularly with the octocorals belonging to the genus Briareum (family Briareidae) [4-7]. It is interesting to note that the briarane-type natural products are major constituents of the extracts of octocorals Briareum spp. distributed in the tropical and subtropical Indo-Pacific Ocean. In the past 35 years, over 500 briarane analogues have been obtained and the number is still increasing based on their structural complexity and interesting bioactivities. It is worth noting that only three hydroperoxybriarane analogues have been isolated to date $[22,32,38]$ and that briarenolide $\mathrm{F}(\mathbf{1})$ is the first 6-hydroperoxybriarane. 7-Hydroxybriarane derivatives are also rarely found [43,50-52]; the new briarane, briarenolide G (2) was the first 7-hydroxybriarane derivative isolated from the octocorals collected off the waters of Taiwan. The study material Briareum sp. has begun to be transplanted in tanks for the extraction of natural products in order to establish a stable supply of bioactive material.

\section{Acknowledgments}

This research was supported by grants from the National Museum of Marine Biology and Aquarium (Grant No. 100100101 and No. 100200311); the National Dong Hwa University: the Division of Marine Biotechnology, Asia-Pacific Ocean Research Center, National Sun Yat-sen University (Grant 
No. 00C-0302-05); the Department of Health Clinical Trial and Research Center of Excellence (Grant No. DOH101-TD-C-111-004); the National Research Program for Biopharmaceuticals, National Science Council (Grant No. NSC 101-2325-B-291-001, 100-2325-B-291-001 and 98-2320-B-291-001-MY3), Taiwan, awarded to Y.-H.K. and P.-J.S.

\section{References}

1. Blunt, J.W.; Copp, B.R.; Keyzers, R.A.; Munro, M.H.G.; Prinsep, M.R. Marine natural products. Nat. Prod. Rep. 2012, 29, 144-222.

2. Berrue, F.; Kerr, R.G. Diterpenes from gorgonian corals. Nat. Prod. Rep. 2009, 26, 681-710.

3. Hanson, J.R. Diterpenoids. Nat. Prod. Rep. 2009, 26, 1156-1171.

4. Sung, P.-J.; Sheu, J.-H.; Xu, J.-P. Survey of briarane-type diterpenoids of marine origin. Heterocycles 2002, 57, 535-579.

5. Sung, P.-J.; Chang, P.-C.; Fang, L.-S.; Sheu, J.-H.; Chen, W.-C.; Chen, Y.-P.; Lin, M.-R. Survey of briarane-related diterpenoids - Part II. Heterocycles 2005, 65, 195-204.

6. Sung, P.-J.; Sheu, J.-H.; Wang, W.-H.; Fang, L.-S.; Chung, H.-M.; Pai, C.-H.; Su, Y.-D.; Tsai, W.-T.; Chen, B.-Y.; Lin, M.-R.; et al. Survey of briarane-type diterpenoids-Part III. Heterocycles 2008, 75, 2627-2648.

7. Sung, P.-J.; Su, J.-H.; Wang, W.-H.; Sheu, J.-H.; Fang, L.-S.; Wu, Y.-C.; Chen, Y.-H.; Chung, H.-M.; Su, Y.-D.; Chang, Y.-C. Survey of briarane-type diterpenoids-Part IV. Heterocycles 2011, 83, 1241-1258.

8. Sheu, J.-H.; Sung, P.-J.; Huang, L.-H.; Lee, S.-F.; Wu, T.; Chang, B.-Y.; Duh, C.-Y.; Fang, L.-S.; Soong, K.; Lee, T.-J. New cytotoxic briaran diterpenes from the Formosan gorgonian Briareum sp. J. Nat. Prod. 1996, 59, 935-938.

9. Sheu, J.-H.; Sung, P.-J.; Cheng, M.-C.; Liu, H.-Y.; Fang, L.-S.; Duh, C.-Y.; Chiang, M.Y. Novel cytotoxic diterpenes, excavatolides A-E, isolated from the Formosan gorgonian Briareum excavatum. J. Nat. Prod. 1998, 61, 602-608.

10. Sung, P.-J.; Su, J.-H.; Wang, G.-H.; Lin, S.-F.; Duh, C.-Y.; Sheu, J.-H. Excavatolides F-M, new briarane diterpenes from the gorgonian Briareum excavatum. J. Nat. Prod. 1999, 62, 457-463.

11. Sheu, J.-H.; Sung, P.-J.; Su, J.-H.; Wang, G.-H.; Duh, C.-Y.; Shen, Y.-C.; Chiang, M.Y.; Chen, I.-T. Excavatolides $\mathrm{U}-\mathrm{Z}$, new briarane diterpenes from the Gorgonian Briareum excavatum. J. Nat. Prod. 1999, 62, 1415-1420.

12. Sheu, J.-H.; Sung, P.-J.; Su, J.-H.; Liu, H.-Y.; Duh, C.-Y.; Chiang, M.Y. Briaexcavatolides A-J, new diterpenes from the gorgonian Briareum excavatum. Tetrahedron 1999, 55, 14555-14564.

13. Sung, P.-J.; Su, J.-H.; Duh, C.-Y.; Chiang, M.Y.; Sheu, J.-H. Briaexcavatolides K-N, new briarane diterpenes from the gorgonian Briareum excavatum. J. Nat. Prod. 2001, 64, 318-323.

14. Wu, S.-L.; Sung, P.-J.; Chiang, M.Y.; Wu, J.-Y.; Sheu, J.-H. New polyoxygenated briarane diterpenoids, briaexcavatolides $\mathrm{O}-\mathrm{R}$, from the gorgonian Briareum excavatum. J. Nat. Prod. 2001, 64, 1415-1420.

15. Wu, S.-L.; Sung, P.-J.; Su, J.-H.; Sheu, J.-H. Briaexcavatolides S-V, four new briaranes from a Formosan gorgonian Briareum excavatum. J. Nat. Prod. 2003, 66, 1252-1256. 
16. Wu, S.-L.; Sung, P.-J.; Su, J.-H.; Wang, G.-H.; Sheu, J.-H. Briaexcavatolide W, a new diterpenoid from Briareum excavatum. Heterocycles 2004, 63, 895-898.

17. Sung, P.-J.; Hu, W.-P.; Wu, S.-L.; Su, J.-H.; Fang, L.-S.; Wang, J.-J.; Sheu, J.-H. Briaexcavatolides $\mathrm{X}-\mathrm{Z}$, three new briarane-related derivatives from the gorgonian coral Briareum excavatum. Tetrahedron 2004, 60, 8975-8979.

18. Sung, P.-J.; Hu, W.-P.; Fang, L.-S.; Fan, T.-Y.; Wang, J.-J. Briarenol A, a new diterpenoid from a gorgonian Briareum sp. (Briareidae). Nat. Prod. Res. 2005, 19, 689-694.

19. Sung, P.-J.; Chao, C.-H.; Chen, Y.-P.; Su, J.-H.; Hu, W.-P.; Sheu, J.-H. Briaexcavatins A and B, novel briaranes from the octocoral Briareum excavatum. Tetrahedron Lett. 2006, 47, 167-170.

20. Sung, P.-J.; Chen, Y.-P.; Hwang, T.-L.; Hu, W.-P.; Fang, L.-S.; Wu, Y.-C.; Li, J.-J.; Sheu, J.-H. Briaexcavatins $\mathrm{C}-\mathrm{F}$, four new briarane-related diterpenoids from the Formosan octocoral Briareum excavatum (Briareidae). Tetrahedron 2006, 62, 5686-5691.

21. Chen, Y.-P.; Wu, S.-L.; Su, J.-H.; Lin, M.-R.; Hu, W.-P.; Hwang, T.-L.; Sheu, J.-H.; Fan, T.-Y.; Fang, L.-S.; Sung, P.-J. Briaexcavatins G and H, two new briaranes from the octocoral Briareum excavatum. Bull. Chem. Soc. Jpn. 2006, 79, 1900-1905.

22. Su, J.-H.; Sung, P.-J.; Kuo, Y.-H.; Hsu, C.-H.; Sheu, J.-H. Briarenolides A-C, briarane diterpenoids from the gorgonian coral Briareum sp. Tetrahedron 2007, 63, 8282-8285.

23. Sung, P.-J.; Lin, M.-R.; Su, Y.-D.; Chiang, M.Y.; Hu, W.-P.; Su, J.-H.; Cheng, M.-C.; Hwang, T.-L.; Sheu, J.-H. New briaranes from the octocorals Briareum excavatum (Briareidae) and Junceella fragilis (Ellisellidae). Tetrahedron 2008, 64, 2596-2604.

24. Sung, P.-J.; Lin, M.-R.; Hwang, T.-L.; Fan, T.-Y.; Su, W.-C.; Ho, C.-C.; Fang, L.-S.; Wang, W.-H. Briaexcavatins $\mathrm{M}-\mathrm{P}$, four new briarane-related diterpenoids from cultured octocoral Briareum excavatum (Briareidae). Chem. Pharm. Bull. 2008, 56, 930-935.

25. Hwang, T.-L.; Lin, M.-R.; Tsai, W.-T.; Yeh, H.-C.; Hu, W.-P.; Sheu, J.-H.; Sung, P.-J. New polyoxygenated briaranes from octocorals Briareum excavatum and Ellisella robusta. Bull. Chem. Soc. Jpn. 2008, 81, 1638-1646.

26. Sung, P.-J.; Lin, M.-R.; Chiang, M.Y. The structure and absolute stereochemistry of briaexcavatin U, a new chlorinated briarane from a cultured octocoral Briareum excavatum. Chem. Lett. 2009, $38,154-155$.

27. Sung, P.-J.; Lin, M.-R.; Chiang, M.Y.; Hwang, T.-L. Briaexcavatins V-Z, discovery of new briaranes from a cultured octocoral Briareum excavatum. Bull. Chem. Soc. Jpn. 2009, 82, 987-996.

28. Sung, P.-J.; Su, Y.-D.; Li, G.-Y.; Chiang, M.Y.; Lin, M.-R.; Huang, I-C.; Li, J.-J.; Fang, L.-S.; Wang, W.-H. Excavatoids A-D, new polyoxygenated briaranes from the octocoral Briareum excavatum. Tetrahedron 2009, 65, 6918-6924.

29. Sung, P.-J.; Chen, B.-Y.; Lin, M.-R.; Hwang, T.-L.; Wang, W.-H.; Sheu, J.-H.; Wu, Y.-C. Excavatoids E and F: Discovery of two new briaranes from the cultured octocoral Briareum excavatum. Mar. Drugs 2009, 7, 472-482.

30. Sung, P.-J.; Chen, B.-Y.; Chiang, M.Y.; Hou, C.-H.; Su, Y.-D.; Hwang, T.-L.; Chen, Y.-H.; Chen, J.-J. Excavatoids G-K, new 8,17-epoxybriaranes from the cultured octocoral Briareum excavatum (Briareidae). Bull. Chem. Soc. Jpn. 2010, 83, 539-545. 
31. Su, J.-H.; Chen, B.-Y.; Hwang, T.-L.; Chen, Y.-H.; Huang, I.-C.; Lin, M.-R.; Chen, J.-J.; Fang, L.-S.; Wang, W.-H.; Li, J.-J.; et al. Excavatoids L-N, new 12-hydroxybriaranes from the cultured octocoral Briareum excavatum (Briareidae). Chem. Pharm. Bull. 2010, 58, 662-665.

32. Sung, P.-J.; Lin, M.-R.; Chiang, M.Y.; Syu, S.-M.; Fang, L.-S.; Wang, W.-H.; Sheu, J.-H. Briarenolide D, a new hydroperoxybriarane diterpenoid from a cultured octocoral Briareum sp. Chem. Lett. 2010, 39, 1030-1032.

33. Sung, P.-J.; Li, G.-Y.; Su, Y.-D.; Lin, M.-R.; Chang, Y.-C.; Kung, T.-H.; Lin, C.-S.; Chen, Y.-H.; $\mathrm{Su}$, J.-H.; Lu, M.-C.; et al. Excavatoids $\mathrm{O}$ and P, new 12-hydroxybriaranes from the octocoral Briareum excavatum. Mar. Drugs 2010, 8, 2639-2646.

34. Hong, P.-H.; Su, Y.-D.; Lin, N.-C.; Chen, Y.-H.; Kuo, Y.-H.; Hwang, T.-L.; Wang, W.-H.; Chen, J.-J.; Sheu, J.-H.; Sung, P.-J. Briarenolide E: The first 2-ketobriarane diterpenoid from an octocoral Briareum sp. (Briareidae). Tetrahedron Lett. 2012, 53, 1710-1712.

35. Yeh, T.-T.; Wang, S.-K.; Dai, C.-F.; Duh, C.-Y. Briacavatolides A-C, new briaranes from the Taiwanese octocoral Briareum excavatum. Mar. Drugs 2012, 10, 1019-1026.

36. Chang, Y.-C.; Huang, I-C.; Chiang, M.Y.; Hwang, T.-L.; Kung, T.-H.; Lin, C.-S.; Sheu, J.-H.; Sung, P.-J. Briaviodiol A, a new cembranoid from a soft coral Briareum violacea. Chem. Pharm. Bull. 2010, 58, 1666-1668.

37. Sung, P.-J.; Chen, B.-Y.; Chen, Y.-H.; Chiang, M.Y.; Lin, M.-R. Loliolide: Occurrence of a carotenoid metabolite in the octocoral Briareum excavatum (Briareidae). Biochem. Syst. Ecol. 2010, 38, 116-118.

38. Aoki, S.; Okano, M.; Matsui, K.; Itoh, T.; Satari, R.; Akiyama, S.-I.; Kobayashi, M. Brianthein A, a novel briarane-type diterpene reversing multidrug resistance in human carcinoma cell line, from the gorgonian Briareum excavatum. Tetrahedron 2001, 57, 8951-8957.

39. Allinger, N.L. Conformational analysis. 130. MM2. A hydrocarbon force field utilizing $V_{1}$ and $V_{2}$ torsional terms. J. Am. Chem. Soc. 1977, 99, 8127-8134.

40. Guerriero, A.; D’Ambrosio, M.; Pietra, F. Slowly interconverting conformers of the briarane diterpenoids verecynarmin B, C, and D, isolated from the nudibranch mollusc Armina maculata and the Pennatulacean octocoral Veretillum cynomorium of East Pyrenean waters. Helv. Chim. Acta 1988, 71, 472-485.

41. Anjaneyulu, A.S.R.; Rao, N.S.K. Juncins G and H: New briarane diterpenoids of the Indian Ocean gorgonian Junceella juncea Pallas. J. Chem. Soc. Perkin Trans. 1 1997, 959-962.

42. Sung, P.-J.; Lin, M.-R.; Chen, W.-C.; Fang, L.-S.; Lu, C.-K.; Sheu, J.-H. Fragilide A, a novel diterpenoid from Junceella fragilis. Bull. Chem. Soc. Jpn. 2004, 77, 1229-1230.

43. Ospina, C.A.; Rodríguez, A.D. Bioactive compounds from the gorgonian Briareum polyanthes. Correction of the structures of four asbestinane-type diterpenes. J. Nat. Prod. 2006, 69, $1721-1727$.

44. Bayer, F.M. Key to the genera of octocorallia exclusive of Pennatulacea (Coelenterata: Anthozoa), with diagnoses of new taxa. Proc. Biol. Wash. Soc. 1981, 94, 902-947.

45. Benayahu, Y. Soft corals (Octocorallia: Alcyonacea) of the southern Ryukyu Archipelago: The families Tubiporidae, Clavulariidae, Alcyoniidae and Briareidae. Galaxea 2002, 4, 11-32. 
46. Benayahu, Y.; Jeng, M.-S.; Perkol-Finkel, S.; Dai, C.-F. Soft corals (Octocorallia: Alcyonacea) from Southern Taiwan. II. Species diversity and distributional patterns. Zool. Stud. 2004, 43, $548-560$.

47. Fabricius, K.; Alderslade, P. Soft Corals and Sea Fans-A Comprehensive Guide to the Tropical Shallow-Water Genera of the Central-West Pacific, the Indian Ocean and the Red Sea, 1st ed.; Australian Institute of Marine Science: Queensland, Australia, 2001; pp. 55, 154-157.

48. Yu, H.-P.; Hsieh, P.-W.; Chang, Y.-J.; Chung, P.-J.; Kuo, L.-M.; Hwang, T.-L. 2-(2-Fluorobenzamido)benzoate ethyl ester (EFB-1) inhibits superoxide production by human neutrophils and attenuates hemorrhagic shock-induced organ dysfunction in rats. Free Radic. Biol. Med. 2011, 50, 1737-1748.

49. Hwang, T.-L.; Wang, C.-C.; Kuo, Y.-H.; Huang, H.-C.; Wu, Y.-C.; Kuo, L.-M.; Wu, Y.-H. The hederagenin saponin SMG-1 is a natural FMLP receptor inhibitor that suppresses human neutrophil activation. Biochem. Pharmacol. 2010, 80, 1190-1200.

50. Dookran, R.; Maharaj, D.; Mootoo, B.S.; Ramsewak, R.; McLean, S.; Reynolds, W.F.; Tinto, W.F. Briarane and asbestinane diterpenes from Briareum asbestinum. Tetrahedron 1994, 50, 1983-1992.

51. Guerriero, A.; D'Ambrosio, M.; Pietra, F. Bis-allylic reactivity of the funicolides, 5,8(17)-diunsaturated briarane diterpenes of the sea pen Funiculina quadrangularis from the Tuscan Archipelago, leading to 16-nortaxane derivatives. Helv. Chim. Acta 1995, 78, 1465-1478.

52. Xu, L.; Patrick, B.O.; Roberge, M.; Allen, T.; van Ofwegen, L.; Andersen, R.J. New diterpenoids from the octocoral Pachyclavularia violacea collected in Papua New Guinea. Tetrahedron 2000, 56, 9031-9037.

Samples Availability: Not available.

(C) 2012 by the authors; licensee MDPI, Basel, Switzerland. This article is an open access article distributed under the terms and conditions of the Creative Commons Attribution license (http://creativecommons.org/licenses/by/3.0/). 